\title{
Effect of drugs on bone mineral density in postmenopausal osteoporosis: a Bayesian network meta-analysis
}

Filippo Migliorini ${ }^{1 *} \mathbb{D}$, Nicola Maffulli, ${ }^{2,3,4}$, Giorgia Colarossi ${ }^{1}$, Jörg Eschweiler ${ }^{1}$, Markus Tingart ${ }^{1}$ and Marcel Betsch ${ }^{5}$

\begin{abstract}
Background: Osteoporosis affects mostly postmenopausal women, leading to deterioration of the microarchitectural bone structure and low bone mass, with an increased fracture risk with associated disability, morbidity and mortality. This Bayesian network meta-analysis compared the effects of current anti-osteoporosis drugs on bone mineral density.
\end{abstract}

Methods: The present systematic review and network meta-analysis follows the PRISMA extension statement to report systematic reviews incorporating network meta-analyses of health care interventions. The literature search was performed in June 2021. All randomised clinical trials that have investigated the effects of two or more drug treatments on BMD for postmenopausal osteoporosis were accessed. The network comparisons were performed through the STATA Software/MP routine for Bayesian hierarchical random-effects model analysis. The inverse variance method with standardised mean difference (SMD) was used for analysis.

Results: Data from 64 RCTs involving 82,732 patients were retrieved. The mean follow-up was $29.7 \pm 19.6$ months. Denosumab resulted in a higher spine BMD (SMD -0.220; SE 3.379), followed by pamidronate (SMD -5.662; SE 2.635) and zoledronate (SMD -10.701; SE 2.871). Denosumab resulted in a higher hip BMD (SMD -0.256; SE 3.184), followed by alendronate (SMD -17.032; SE 3.191) and ibandronate (SMD -17.250; SE 2.264). Denosumab resulted in a higher femur BMD (SMD 0.097; SE 2.091), followed by alendronate (SMD -16.030; SE 1.702) and ibandronate (SMD -17.000; SE 1.679).

Conclusion: Denosumab results in higher spine BMD in selected women with postmenopausal osteoporosis. Denosumab had the highest influence on hip and femur BMD.

Level of evidence: Level I, Bayesian network meta-analysis of RCTs

Keywords: Osteoporosis, Bone mineral density, Drugs, Denosumab

\footnotetext{
* Correspondence: migliorini.md@gmail.com

'Department of Orthopaedic, Trauma, and Reconstructive Surgery, RWTH

Aachen University Hospital, Pauwelsstraße 30, 52074 Aachen, Germany

Full list of author information is available at the end of the article
}

(c) The Author(s). 2021 Open Access This article is licensed under a Creative Commons Attribution 4.0 International License, which permits use, sharing, adaptation, distribution and reproduction in any medium or format, as long as you give appropriate credit to the original author(s) and the source, provide a link to the Creative Commons licence, and indicate if changes were made. The images or other third party material in this article are included in the article's Creative Commons licence, unless indicated otherwise in a credit line to the material. If material is not included in the article's Creative Commons licence and your intended use is not permitted by statutory regulation or exceeds the permitted use, you will need to obtain permission directly from the copyright holder. To view a copy of this licence, visit http://creativecommons.org/licenses/by/4.0/ The Creative Commons Public Domain Dedication waiver (http://creativecommons.org/publicdomain/zero/1.0/) applies to the data made available in this article, unless otherwise stated in a credit line to the data. 


\section{Introduction}

Osteoporosis is common in postmenopausal women, with microarchitectural deterioration and low bone mass. Approximately, $19 \%$ of men and $30 \%$ of women in Europe and in the USA are at risk for osteoporosis, and annually around 9 million osteoporosis associated fractures occur [1]. Osteoporosis-associated fractures result in increased disability, mortality and health-care costs, and therefore the treatment and prevention of osteoporotic fractures carries significant clinical and public health importance [2].

Current approved pharmacological treatments for postmenopausal osteoporosis can be divided into antiresorptive and anabolic medications [3]. Briefly, antiresorptive drugs reduce bone resorption, whilst anabolic drugs increase bone formation. The most commonly prescribed agents are anti-resorptive drugs, which include bisphosphonates (BP) (e.g. alendronate, risedronate, zoledronic acid, ibandronate, etidronate), selective oestrogen receptor modulators (SERM) (e.g. raloxifene) and the RANK-ligand inhibitor (e.g. denosumab).

BP were discovered during the search for pyrophosphonate analogues, attempting to benefit from the inhibitory effects of pyrophosphates on calcification [4]. BP work by inhibiting the enzyme farnesyl pyrophosphonate synthase in osteoclasts, influencing their affinity for bone mineral uptake $[5,6]$. During early treatment, SERMs decrease bone remodelling by about $20-30 \%$, and thereby result in a modest transitory increase in bone mineral density (BMD) [7]. However, during prolonged therapy, SERMs lead to a decline in BMD, which may account for the only modest reduction in vertebral fracture risk [7].

Denosumab is a monoclonal antibody against the receptor activator of nuclear factor-kappa B ligand (RANK-ligand), a regulator of osteoclast development. By blocking the RANK-ligand with denosumab the activity, survival and recruitment of osteoblast are inhibited.

Anabolic osteoporosis drugs, such as teriparatide, are usually reserved for patients with severe and established osteoporosis. Both medications lead to an increase in trabecular thickness and improved trabecular microstructure via the teriparatide (PTHR1) receptor $[8,9]$. Finally, romosozunab is a novel sclerostin antibody recently approved for the treatment of osteoporosis. Romosozunab has antifracture and anabolic efficacy, increasing bone formation and decreasing bone resorption $[10,11]$.

Network analysis may provide clinically relevant evidence in the absence of randomised controlled trials (RCTs) comparing relevant pharmaceutical treatments for osteoporosis. Therefore, we conducted this network meta-analysis comparing the effects of nine osteoporosis drugs and their effects on BMD in patients with postmenopausal osteoporosis.

\section{Methods \\ Search strategy}

The present systematic review and network metaanalysis follows the PRISMA extension statement for reporting of systematic reviews incorporating network meta-analyses of health care interventions [12]. The follow algorithm guided the preliminary search:

- P (population): postmenopausal osteoporosis

- I (intervention): medical treatments

- C (comparison): denosumab, raloxifene, teriparatide, alendronate, risedronate, zoledronate, ibandronate, etidronate, strontiumranelate

- O (outcomes): BMD

\section{Data source and extraction}

The literature search was performed by two independent authors (FM; GC). In June 2021, the databases search started. The search on PubMed was performed with the following string: osteoporosis [All Fields] AND (bone [All Fields] OR endocrinology [All Fields]) AND (postmenopausal [All Fields] OR treatment [All Fields] OR management [All Fields] OR spine [All Fields] OR femur [All Fields] AND hip [All Fields] OR BMD [All Fields]) AND (mineral density [All Fields] OR Bisphosphonates [All Fields] OR Denosumab [All Fields] OR Raloxifene [All Fields] OR Teriparatide [All Fields] OR Alendronate [All Fields] OR Risedronate [All Fields] OR Zoledronate [All Fields] OR Ibandronate [All Fields] OR Etidronate [All Fields] OR Calcium [All Fields] OR Vitamin D [All Fields] OR PTH [All Fields] OR osteoblast [All Fields] OR osteoclast [All Fields]) AND management [All Fields] OR therapy [All Fields]. The same search strings were used to search Google Scholar, Embase and Scopus. The resulting titles and subsequent abstracts were screened by the same two authors. If they matched the topic, the article full-text was accessed. A cross reference of the bibliographies was also performed. Disagreement was debated and solved by a third senior author (NM).

\section{Eligibility criteria}

All the randomised clinical trials (RCTs) investigating the effects of two or more drug treatments on BMD for postmenopausal osteoporosis were accessed. Given the authors language capabilities, articles in English, German, Italian, French and Spanish were eligible. Only levels I and II RCTs according to the Oxford Centre of Evidence-Based Medicine [13] were considered. Only articles reporting quantitative data under the outcomes of interest and articles with a minimum 12 months followup were considered. Studies treating patients with 
calcium and vitamin D without any other drugs were not included. Studies reporting data on patients with iatrogenic-induced menopause were not included, as well as those treating paediatric and/or adolescent patients. Studies on patients undergoing immunosuppressive therapies or organ transplantation were also not considered. Studies reporting data on patients with malignancies or pathological bone diseases other than osteoporosis were not included. Studies reporting data on mixed treatments or taking advantage from adjuvants were excluded. Editorials, registries, comments, expert opinions and reviews were not eligible. Animals or in vitro studies were also not eligible. Missing data under the outcomes of interest warranted the exclusion from this study.

\section{Outcomes of interest}

Two authors (FM; GC) performed data extraction. Study generalities (author, year, journal, duration of the followup) and patient baseline demographic information were collected: number of samples and related mean age, percentage of female, mean bone mass index (BMI) and mean BMD (overall, spine, hip, femur neck). The following drugs were considered in the analyses: denosumab, raloxifene, teriparatide, alendronate, risedronate, zoledronate, ibandronate and etidronate. The outcome of interest was BMD at last follow-up.

\section{Methodology quality assessment}

The methodological quality assessment was performed by two authors (FM; GC). The risk of bias summary tool of the Review Manager Software (The Nordic Cochrane Collaboration, Copenhagen) was used for evaluation. The following risk of bias was assessed: selection, detection, attrition and other source of bias.

\section{Statistical analysis}

The statistical analyses were performed by the main author (FM). Baseline comparability was assessed through the IBM SPSS software. The analysis of variance (ANOVA) was used for analysis, with $P$ values $>0.1$ was considered satisfactory. The STATA Software/MP, Version 14.1 (StataCorporation, College Station, Texas, USA) was used for the statistical analyses. The NMA was performed through the STATA routine for Bayesian hierarchical random-effects model analysis. The placebo treatment was used as reference group. The inverse variance method was used for analysis, with standardised mean difference (STD) and standard error (SE) effect measures. The overall inconsistency was evaluated through the equation for global linearity via the Wald test, with $P$ values $<0.05$ indicating statistically significant inconsistency. Otherwise, if $P>0.05$ the null hypothesis cannot be rejected, and the consistency assumption could be accepted at the overall level of each treatment. Both confidence $(\mathrm{CI})$ and percentile (PrI) intervals were set at $95 \%$. Edge plot, interval plots and funnel plots were obtained and evaluated.

\section{Results}

\section{Search result}

The primary literature search resulted in 1354 articles. Of them, 477 were RCTs. A further 101 were removed because duplicated. Additional 270 articles were excluded because of the study design $(N=26)$, non-clinical studies $(N=34)$, glucocorticoid-induced osteoporosis $(N$ $=51)$, treatment of bone malignancies $(N=56)$, language limitations $(N=12)$ and others $(N=91)$. A further 42 articles were excluded because it did not report quantitative data under the outcomes of interests. Finally, 64 RCTs were included for analysis. The literature search results are shown in Fig. 1.

\section{Methodological quality assessment}

The risk of bias summary evidenced some point of strength of the present study. First, the randomised design of all the included studies leads to low risk of selection bias. Moreover, most studies performed assessors, patients and personnel blinding, thus leading to a low risk of performance and detection bias. The risk of attrition and reporting bias were both low. The risk to incur in unknown/other bias was low to moderate. Concluding, the risk of bias was low, attesting to the methodological assessment of the present study is a very good quality. The score of each risk of bias item for each included study is shown in Fig. 2.

\section{Patient demographics}

Data from 82,732 patients were retrieved. The mean follow-up was $29.7 \pm 19.6$ months. The mean age of the patients was $67.3 \pm 6.1$ years. The mean BMI was $25.0 \pm$ $1.7 \mathrm{~kg} / \mathrm{m}^{2}$. The mean BMD at baseline of the spine was $0.83 \pm 0.11$, of the hip was $0.74 \pm 0.07$ and of the femoral neck was $0.63 \pm 0.07 \mathrm{~g} / \mathrm{cm}^{2}$. The ANOVA test found baseline comparability $(P>0.1)$ with regards to age, BMI and BMD. Studies' generalities and patients' demographics are shown in Table 1.

\section{Outcomes of interest}

Denosumab resulted in a higher spine BMD (SMD -0.22 ; SE 3.38; $95 \%$ CI -6.84 to 6.40 ), followed by pamidronate (SMD -5.66; SE 2.64; 95\% CI -10.83 to -0.50 ) and zoledronate (SMD -10.70; SE 2.87; 95\% CI -16.33 to -5.07). Denosumab resulted in a higher hip BMD (SMD -0.26; SE 3.18; 95\% CI -6.50 to 5.98), followed by alendronate (SMD -17.03; SE 3.19; 95\% CI -23.29 to -10.78) and ibandronate (SMD -17.25; SE 2.26; 95\% CI -21.69 to -12.81$)$. Denosumab resulted in a higher 


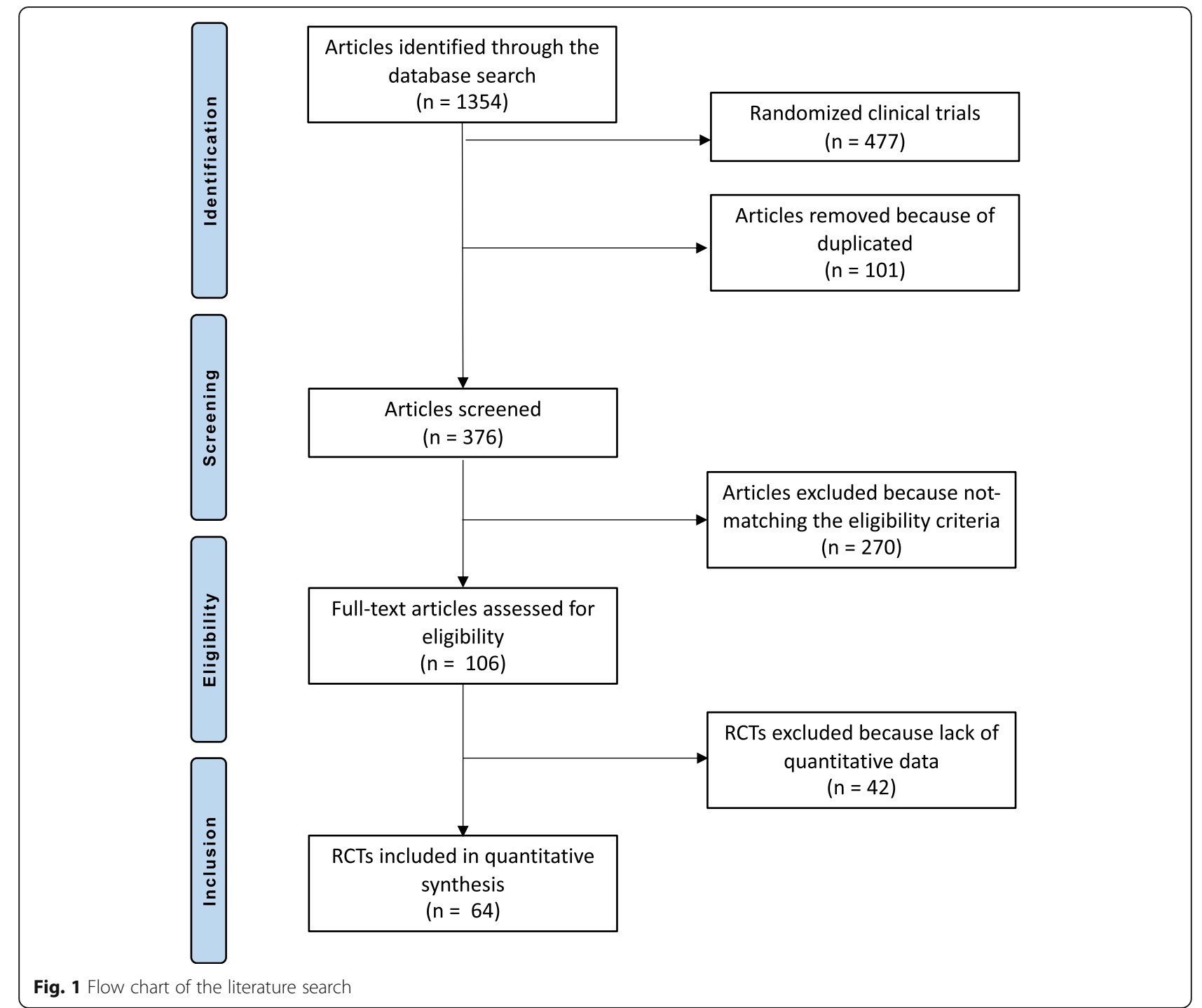

femur BMD (SMD 0.10; SE 2.09; 95\% CI -4.00 to 4.20), followed by alendronate (SMD -16.03; SE 1.70; 95\% CI -19.37 to -12.69 ) and ibandronate (SMD -17.00; SE 1.68; $95 \%$ CI -20.29 to -13.71 ). The equation for global linearity found no statistically significant inconsistency $(P>0.05)$ in all comparisons. Edge, funnel and interval plots of these comparisons are shown in Fig. 3.

\section{Discussion}

Over the last decades, effective pharmaceutical treatments have been developed for the management of osteoporosis. However, most studies have not included multiple active comparators because of cost constraints, ethical problems and government regulations. This network meta-analysis is the first to include 64 RCTs with a total of 82,732 patients, including only studies with levels of evidence 1 and 2 . This study compared and evaluated the influence of currently available pharmacological treatments for osteoporosis with one another in terms of BMD. The present investigation shows that denosumab was associated with the highest BMD of all evaluated osteoporosis drugs in selected women with postmenopausal osteoporosis.

Meta-analyses are considered valuable tools to analyse different studies. However, they only allow a pair-wise assessment of treatments. In contrast, network metaanalyses allow to blend together information over a network of comparisons to compare the relative effects of different treatments used for the same condition. Network meta-analysis provides vital clinical information by ranking the relative efficacy of all interventions, even those which have not been compared with one another directly.

Most previous network meta-analyses have investigated the effects of osteoporosis treatments on fracture risk, which is in contrast to our analysis which instead 


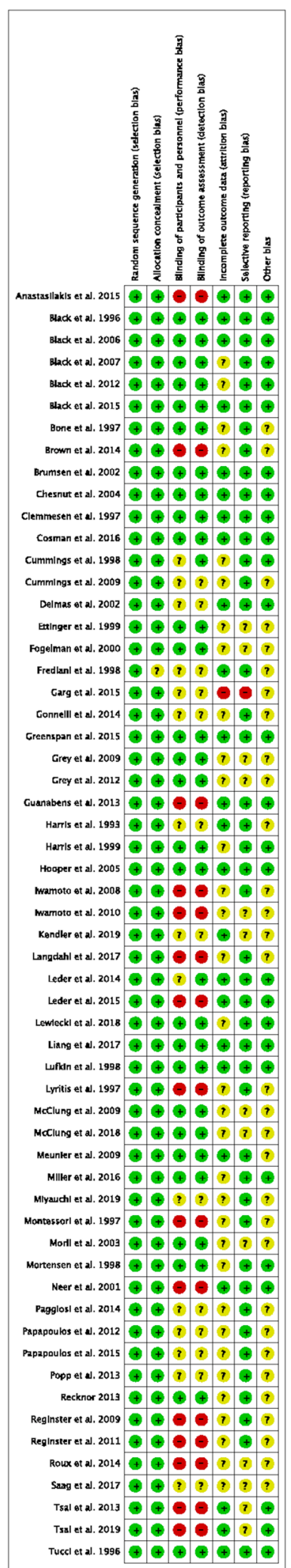

Fig. 2 Methodological quality assessment focused on the influence of drugs on BMD. A recent network meta-analysis of 22 RCTs studied the relative efficacy of 10 osteoporosis drugs in postmenopausal women at high risk of fragility fractures [14]. Abaloparatide had the highest probability of preventing vertebral, non-vertebral, and wrist fractures compared to placebo and all other treatment options. This was also confirmed by another network meta-analysis of 67,524 patients: both abaloparatide and teriparatide significantly reduced the fracture risk compared to placebo and other osteoporosis medications [15]. In addition, a further network meta-analysis confirmed that teriparatide seemed to be most effective in preventing new non-vertebral fractures in patients with osteoporosis [16]. A systematic review and network meta-analysis of RCTs evidenced that nonbisphosphonate interventions (including denosumab, raloxifene, teriparatide, romosozunab) are clinically effective in reducing vertebral fractures compared to placebo, and that they are beneficial for change in femoral neck BMD [17]. Romosozunab, followed by alendronate, resulted in the greatest effect on femoral BMD.

Previous studies suggest that anabolic osteoporosis treatments, such as abaloparatide and teriparatide, exert the highest influence on reducing the overall fracture risk. The present study shows that denosumab has the greatest effect on BMD, independent of the fracture risk. Denosumab demonstrates a high affinity and specificity to the RANKL, and therefore prevents it from binding to the RANKL receptors on osteoclasts and their precursors, with a direct effect on the activity and life span of existing osteoblasts [18]. Denosumab increases BMD by inhibiting bone resorption and remodelling [19]. The FREEDOM trial confirmed that denosumab, administrated every 6 months, significantly reduces the hip fracture risk by $40 \%$, the non-vertebral fracture risk by $20 \%$ and the vertebral fracture risk by $68 \%$ [20].

The extension of the FREEDOM study showed that treatment with denosumab up to 10 years results in a cumulative gain in BMD of $21.7 \%$ at the lumbar spine, and $9.2 \%$ at the total hip, compared to baseline [21]. Denosumab resulted in lower rates of new vertebral and non-vertebral fractures throughout the study period [21]. Denosumab is administrated subcutaneously every 6 months, and therefore it is likely that the adherence to the medication is better compared to BP. This was confirmed by Kendler et al., who showed greater satisfaction when patients transitioned to denosumab as compared to a monthly oral BP [22]. Palacios et al. also confirmed a higher adherence of patients to denosumab compared to $\mathrm{BP}$, and that most patients do prefer denosumab over BP for the treatment of osteoporosis [23]. The advantages of denosumab over BP seem the more favourable side-effect profile (low rates of infections and malignancies), and, as shown in the present study, the more 


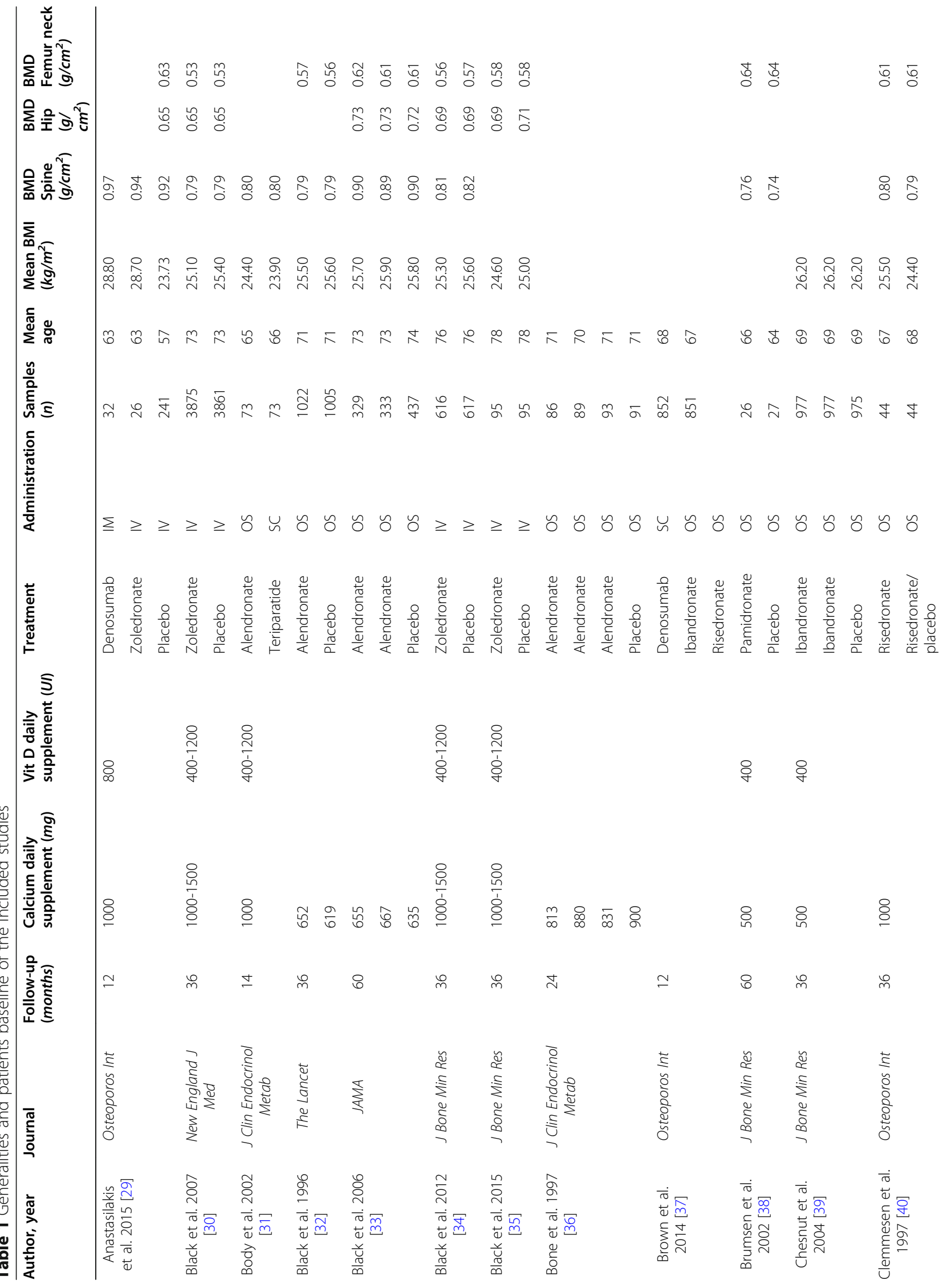




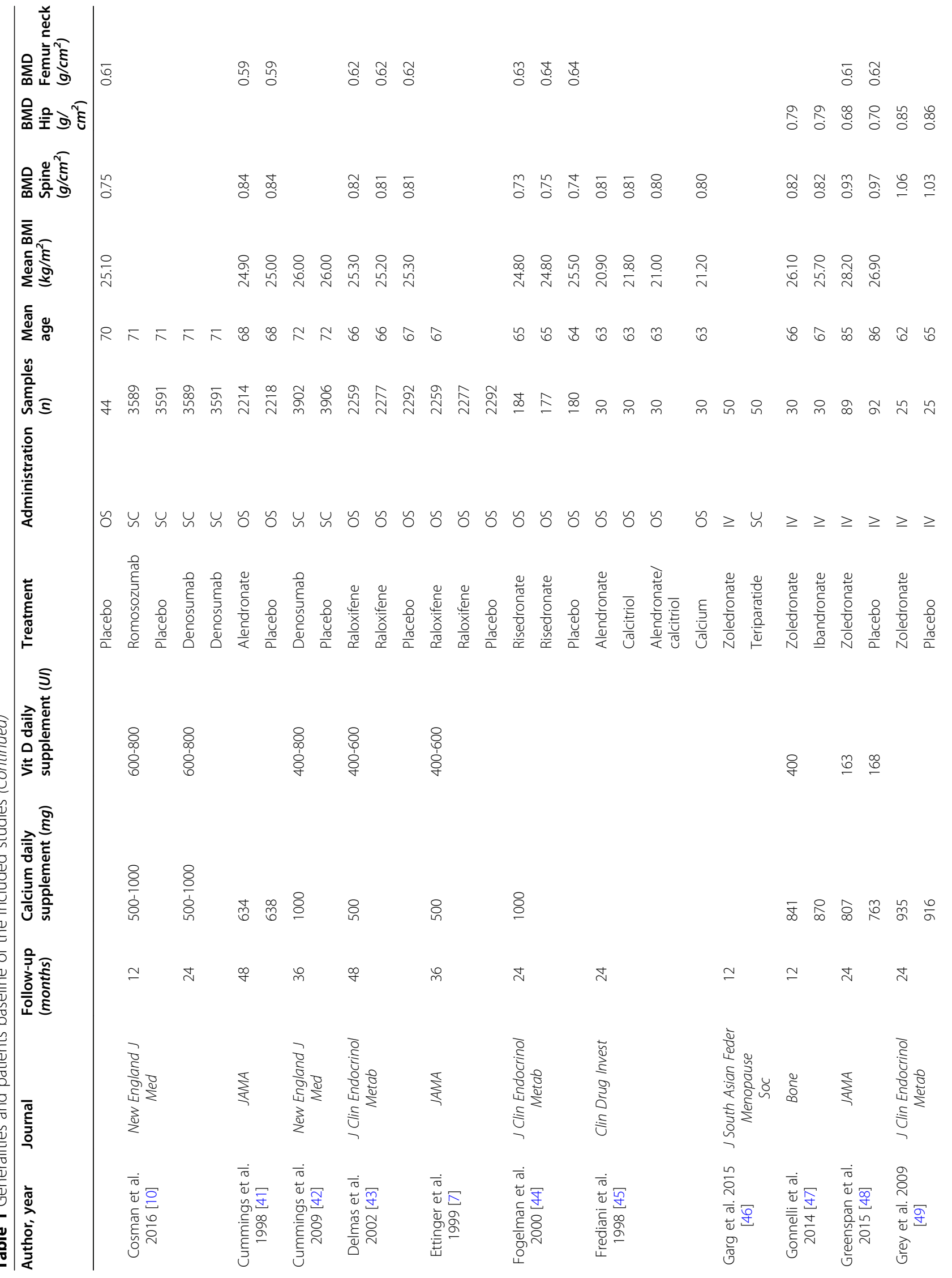




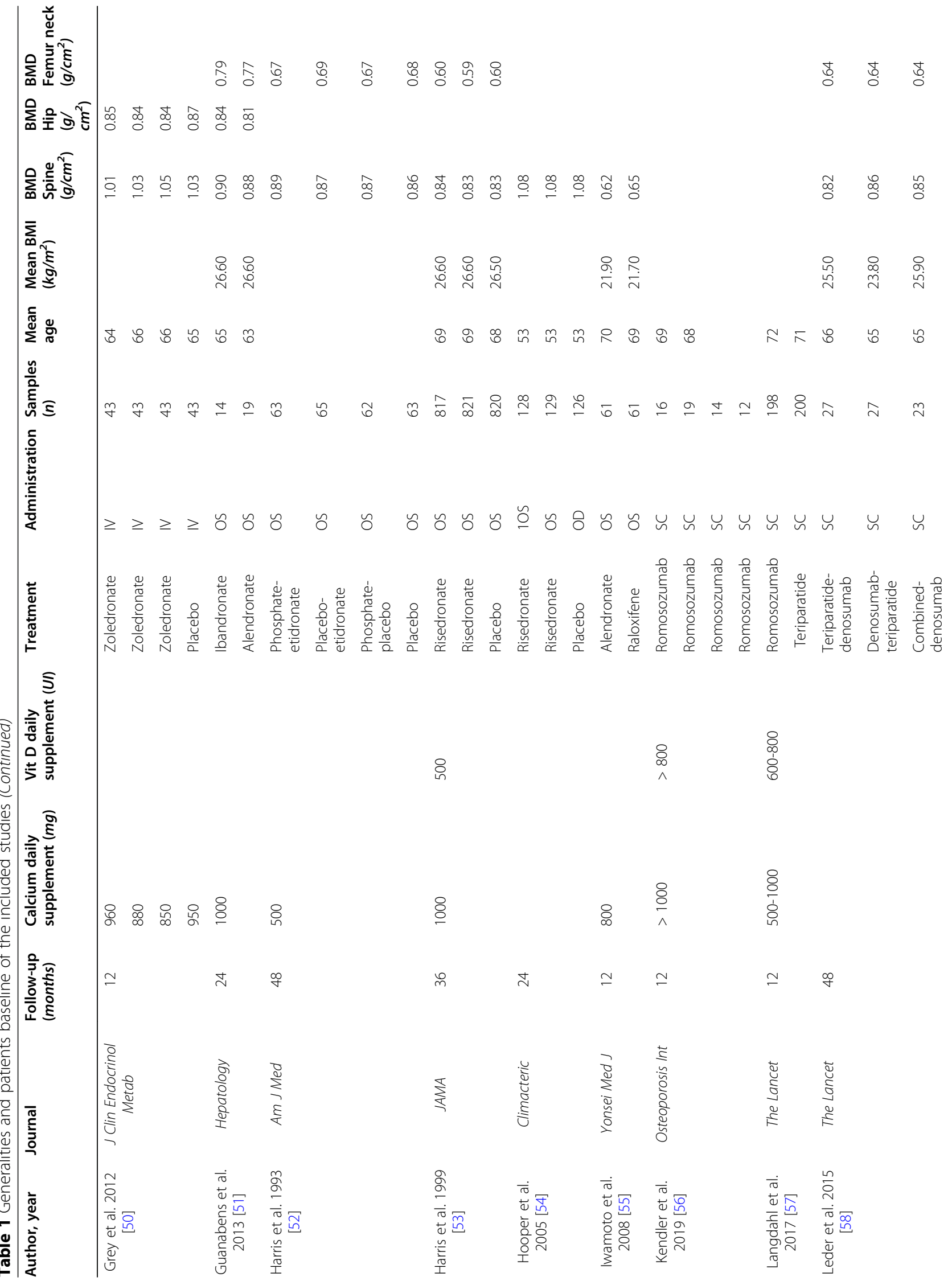




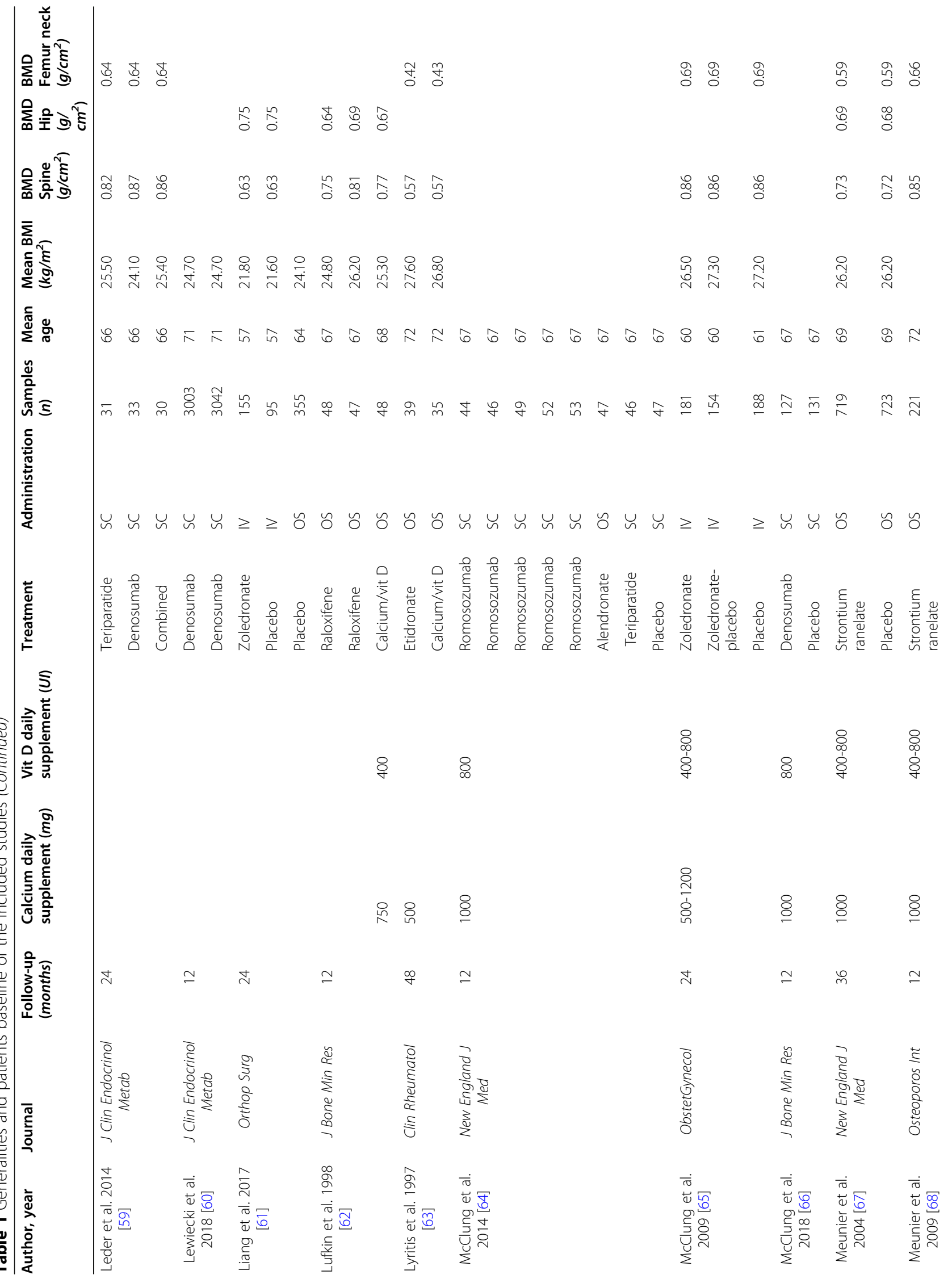




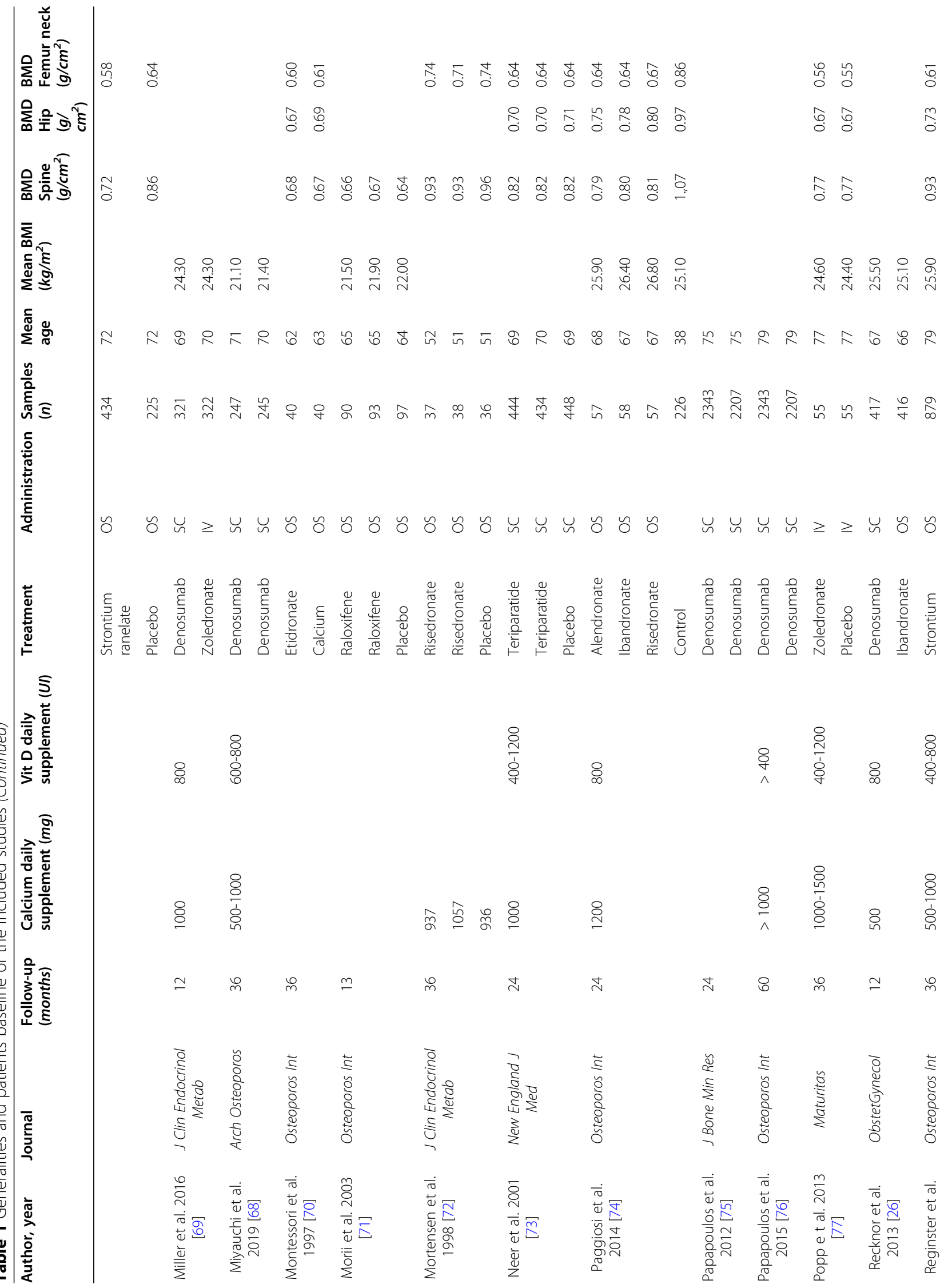




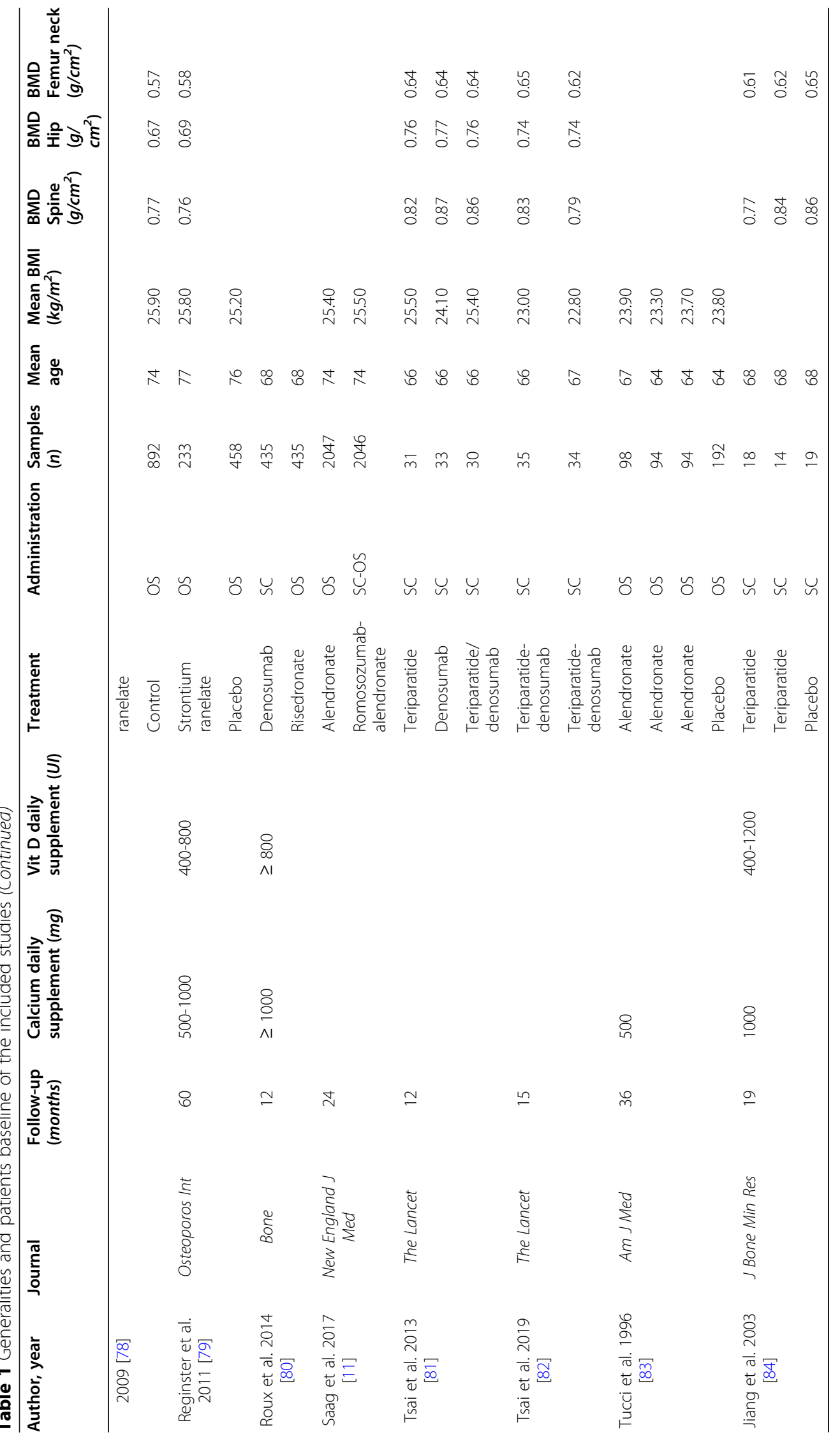




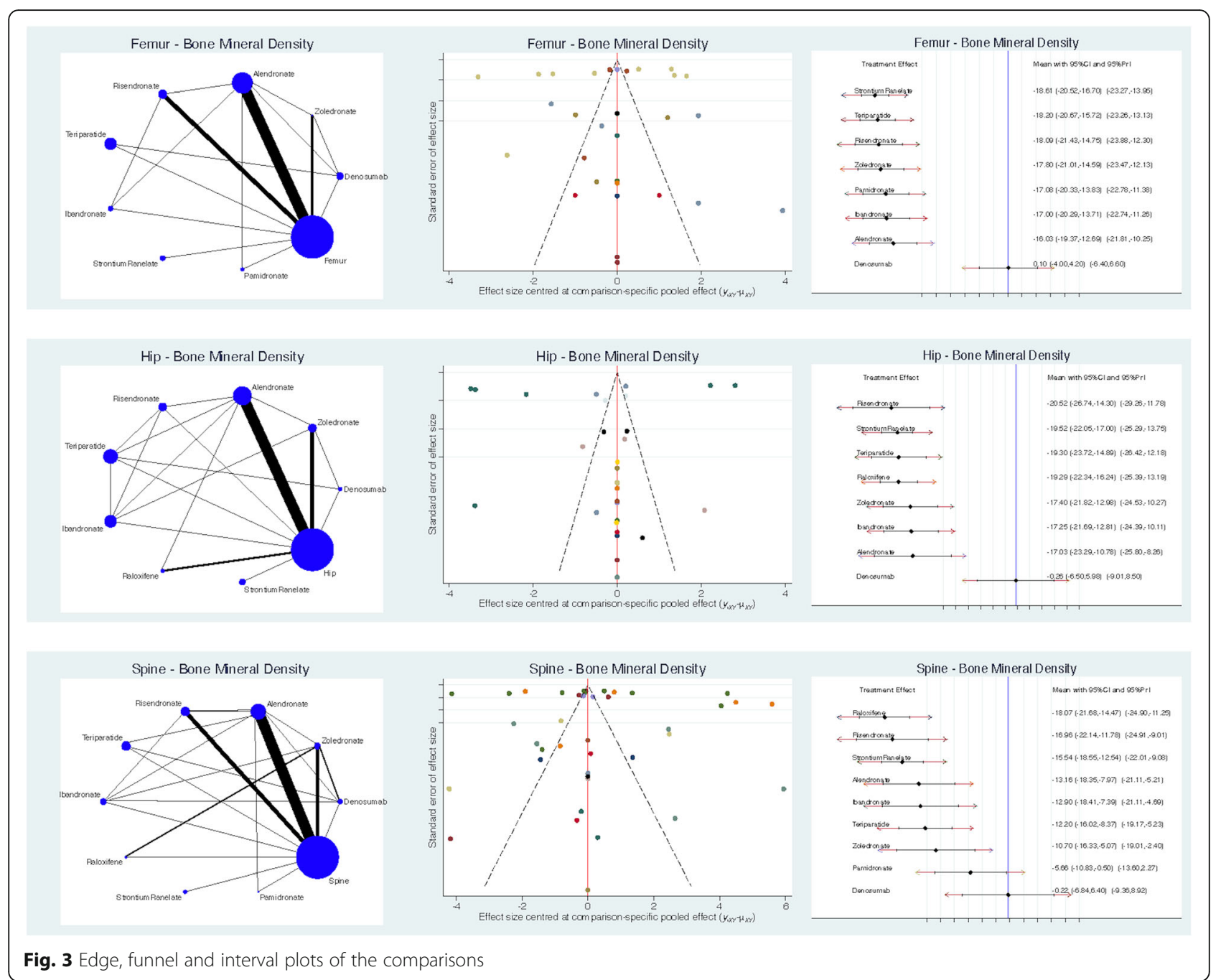

pronounced beneficial effects on BMD. This was also confirmed previously, with denosumab more effective than ibandronate and alendronate [24-28].

Limitations of this network meta-analysis include the focus on the effects of osteoporosis treatments on spinal and hip BMD without an assessment of fracture risk reduction, adverse events or costs. The investigation of adverse effects seems to be particularly important, since adverse effects can affect adherence to treatment. Also, we only included studies which evaluated the effects of anti-osteoporosis medications for postmenopausal osteoporosis, but not for age-related, senile, or secondary osteoporosis. Further studies are necessary to examine these aspects. The minimum follow-up for a study to be included in the present network meta-analysis was 1 year. However, osteoporosis requires long-term treatment to produce clinically relevant benefits. This is especially important when certain medications, such as denosumab, have to be discontinued, and thereby lead to a potential increase in fracture risk. Another potential limitation is related to the limited variety of drugs included for analysis. Given the lack of studies in the literature, some commonly used medications, such as abaloparatide and romosozumab, were not included in the analyses. In light of these limitations, data from the present Bayesian network meta-analysis must be interpreted with caution.

Strengths of our study are the comprehensive literature search of multiple databases in multiple languages, which led to the inclusion of 64 evidence levels I and II RCTs with a total of 82,732 interventions. We also performed a rigorous review process, which was performed by two independent reviewers. Finally, we summarised and analysed the latest evidence of anti-osteoporosis medications on BMD in postmenopausal women from RCTs with the highest levels of evidence, which to our knowledge has not been performed before. 


\section{Conclusion}

The present network meta-analysis shows that denosumab followed by pamidronate and zoledronate is associated with higher spine BMD in selected women with postmenopausal osteoporosis. Denosumab followed by alendronate and ibandronate had the highest influence on hip and femoral BMD. Future studies should evaluate the effects of anti-osteoporosis drugs on the overall fracture risk and on other types of osteoporosis.

\section{Abbreviations}

BMD: Bone mineral density; RANK-ligand: Receptor activator of nuclear factor-kappa B ligand; SERM: Selective oestrogen receptor modulators; BP: Bisphosphonates; PTHR1: Teriparatide; RCTs: Randomised controlled trials; SMD: Standardised mean difference; ANOVA: Analysis of variance; STD: Standardised mean difference; SE: Standard error; Cl: Confidence interval; Prl: Percentile interval; BMl: Body mass index

\section{Acknowledgements}

None

\section{Authors' contributions}

FM: literature search, data extraction, methodological quality assessment, statistical analyses, writing; NM: supervision, revision, final approval; GC: literature search, data extraction, methodological quality assessment; MB: writing; JE, MOB; MT: supervision.

\section{Funding}

No external source of funding was used. Open Access funding enabled and organized by Projekt DEAL.

\section{Availability of data and materials}

This study does not contain any third material.

\section{Declarations}

\section{Ethics approval and consent to participate}

This article does not contain any studies with human participants or animals performed by any of the authors.

\section{Consent for publication}

All the authors approved the manuscript.

\section{Competing interests}

The authors declare that they have no competing interests.

\begin{abstract}
Author details
${ }^{1}$ Department of Orthopaedic, Trauma, and Reconstructive Surgery, RWTH Aachen University Hospital, Pauwelsstraße 30, 52074 Aachen, Germany. ${ }^{2}$ Department of Medicine, Surgery and Dentistry, University of Salerno, Via S. Allende, 84081 Baronissi, Salerno, Italy. ${ }^{3}$ Queen Mary University of London, Barts and the London School of Medicine and Dentistry, Centre for Sports and Exercise Medicine, Mile End Hospital, 275 Bancroft Road, London E1 4DG, England. ${ }^{4}$ School of Pharmacy and Bioengineering, Keele University Faculty of Medicine, Thornburrow Drive, Stoke on Trent, England. ${ }^{5}$ Department of Orthopaedics and Trauma Surgery, University Hospital Mannheim, Medical Faculty of the University Heidelberg, Mannheim, Germany.
\end{abstract}

Received: 27 April 2021 Accepted: 16 August 2021

Published online: 27 August 2021

\section{References}

1. Modi A, Sajjan S, Gandhi S. Challenges in implementing and maintaining osteoporosis therapy. Int J Women's Health. 2014;6:759-69.

2. Compston JE, McClung MR, Leslie WD. Osteoporosis. Lancet. 2019; 393(10169):364-76. https://doi.org/10.1016/S0140-6736(18)32112-3.
3. Canalis E, Giustina A, Bilezikian JP. Mechanisms of anabolic therapies for osteoporosis. N Engl J Med. 2007;357(9):905-16. https://doi.org/10.1056/ NEJMra067395.

4. Anastasilakis AD, Polyzos SA, Makras P. Therapy of endocrine disease: denosumab vs bisphosphonates for the treatment of postmenopausal osteoporosis. Eur J Endocrinol. 2018;179(1):R31-45. https://doi.org/10.1530/ EJE-18-0056.

5. van Beek E, Pieterman E, Cohen L, Löwik C, Papapoulos S. Farnesyl pyrophosphate synthase is the molecular target of nitrogen-containing bisphosphonates. Biochem Biophys Res Commun. 1999;264(1):108-11. https://doi.org/10.1006/bbrc.1999.1499.

6. Kavanagh KL, Guo K, Dunford JE, Wu X, Knapp S, Ebetino FH, et al. The molecular mechanism of nitrogen-containing bisphosphonates as antiosteoporosis drugs. Proc Natl Acad Sci U S A. 2006;103(20):7829-34. https://doi.org/10.1073/pnas.0601643103.

7. Ettinger B, Black DM, Mitlak BH, Knickerbocker RK, Nickelsen T, Genant HK, et al. Reduction of vertebral fracture risk in postmenopausal women with osteoporosis treated with raloxifene: results from a 3-year randomized clinical trial. Multiple Outcomes of Raloxifene Evaluation (MORE) Investigators. JAMA. 1999;282(7):637-45. https://doi.org/10.1001/ jama.282.7.637.

8. Chen P, Miller PD, Recker R, Resch H, Rana A, Pavo I, et al. Increases in BMD correlate with improvements in bone microarchitecture with teriparatide treatment in postmenopausal women with osteoporosis. J Bone Miner Res. 2007;22(8):1173-80. https://doi.org/10.1359/jbmr.070413.

9. Bahar H, Gallacher K, Downall J, Nelson CA, Shomali M, Hattersley G. Six weeks of daily abaloparatide treatment increased vertebral and femoral bone mineral density, microarchitecture and strength in ovariectomized osteopenic rats. Calcif Tissue Int. 2016;99(5):489-99. https://doi.org/10.1007/ s00223-016-0171-1.

10. Cosman F, Crittenden DB, Adachi JD, Binkley N, Czerwinski E, Ferrari S, et al. Romosozumab treatment in postmenopausal women with osteoporosis. N Engl J Med. 2016;375(16):1532-43. https://doi.org/10.1056/NEJMoa1607948.

11. Saag KG, Petersen J, Brandi ML, Karaplis AC, Lorentzon M, Thomas T, et al. Romosozumab or alendronate for fracture prevention in women with osteoporosis. N Engl J Med. 2017;377(15):1417-27. https://doi.org/10.1056/ NEJMoa1708322.

12. Hutton B, Salanti G, Caldwell DM, Chaimani A, Schmid CH, Cameron C, et al. The PRISMA extension statement for reporting of systematic reviews incorporating network meta-analyses of health care interventions: checklist and explanations. Ann Intern Med. 2015;162(11):777-84. https://doi.org/10. 7326/M14-2385.

13. Howick J Cl, Glasziou P, Greenhalgh T, Carl Heneghan, Liberati A, Moschetti I, Phillips B, Thornton H, Goddard O, Hodgkinson M. 2011. The 2011 Oxford CEBM levels of evidence. Oxford Centre for Evidence-Based Medicine Available at https://www.cebmnet/indexaspx?o=5653.

14. Reginster J, Bianic F, Campbell R, et al. Abaloparatide for risk reduction of nonvertebral and vertebral fractures in postmenopausal women with osteoporosis: a network meta-analysis. Osteoporos Int. 2019;30(7):1465-73. https://doi.org/10.1007/s00198-019-04947-2.

15. Tan X, Wen F, Yang W, Xie JY, Ding LL, Mo YX. Comparative efficacy and safety of pharmacological interventions for osteoporosis in postmenopausal women: a network meta-analysis (Chongqing, China). Menopause. 2019; 26(8):929-39. https://doi.org/10.1097/GME.0000000000001321.

16. Yang XC, Deng ZH, Wen T, Luo W, Xiao WF, Zhao RB, et al. Network metaanalysis of pharmacological agents for osteoporosis treatment and fracture prevention. Cell Physiol Biochem. 2016;40(3-4):781-95. https://doi.org/10.11 59/000453138.

17. Simpson EL, Martyn-St James M, Hamilton J, Wong R, Gittoes N, Selby P, et al. Clinical effectiveness of denosumab, raloxifene, romosozumab, and teriparatide for the prevention of osteoporotic fragility fractures: a systematic review and network meta-analysis. Bone. 2020;130:115081. https://doi.org/10.1016/j.bone.2019.115081.

18. Chandran T, Venkatachalam I. Efficacy and safety of denosumab compared to bisphosphonates in improving bone strength in postmenopausal osteoporosis: a systematic review. Singap Med J. 2019;60(7):364-78. https:// doi.org/10.11622/smedj.2019028.

19. Sornay-Rendu E, Boutroy S, Munoz F, Bouxsein ML. Cortical and trabecular architecture are altered in postmenopausal women with fractures. Osteoporos Int. 2009;20(8):1291-7. https://doi.org/10.1007/s001 98-009-1008-9. 
20. Zaheer S, LeBoff M, Lewiecki EM. Denosumab for the treatment of osteoporosis. Expert Opin Drug Metab Toxicol. 2015;11(3):461-70. https:// doi.org/10.1517/17425255.2015.1000860.

21. Bone HG, Wagman RB, Brandi ML, Brown JP, Chapurlat R, Cummings SR, et al. 10 years of denosumab treatment in postmenopausal women with osteoporosis: results from the phase 3 randomised FREEDOM trial and open-label extension. Lancet Diabetes Endocrinol. 2017;5(7):513-23. https:// doi.org/10.1016/S2213-8587(17)30138-9.

22. Kendler DL, Macarios D, Lillestol MJ, Moffett A, Satram-Hoang S, Huang J, et al. Influence of patient perceptions and preferences for osteoporosis medication on adherence behavior in the Denosumab Adherence Preference Satisfaction study. Menopause. 2014;21(1):25-32. https://doi.org/1 0.1097/GME.0b013e31828f5e5d.

23. Palacios S, Agodoa I, Bonnick S, van den Bergh JP, Ferreira I, Ho PR, et al. Treatment satisfaction in postmenopausal women suboptimally adherent to bisphosphonates who transitioned to denosumab compared with risedronate or ibandronate. J Clin Endocrinol Metab. 2015;100(3):E487-92. https://doi.org/10.1210/jc.2014-3594.

24. Brown JP, Prince RL, Deal C, Recker RR, Kiel DP, de Gregorio LH, et al. Comparison of the effect of denosumab and alendronate on BMD and biochemical markers of bone turnover in postmenopausal women with low bone mass: a randomized, blinded, phase 3 trial. J Bone Miner Res. 2009; 24(1):153-61. https://doi.org/10.1359/jbmr.0809010.

25. Kendler DL, Roux C, Benhamou CL, Brown JP, Lillestol M, Siddhanti S, et al. Effects of denosumab on bone mineral density and bone turnover in postmenopausal women transitioning from alendronate therapy. J Bone Miner Res. 2010;25(1):72-81. https://doi.org/10.1359/jbmr.090716.

26. Recknor C, Czerwinski E, Bone HG, Bonnick SL, Binkley N, Palacios S, et al. Denosumab compared with ibandronate in postmenopausal women previously treated with bisphosphonate therapy: a randomized open-label trial. Obstet Gynecol. 2013;121(6):1291-9. https://doi.org/10.1097/AOG.0b013 e318291718c.

27. Seeman E, Delmas PD, Hanley DA, Sellmeyer D, Cheung AM, Shane E, et al. Microarchitectural deterioration of cortical and trabecular bone: differing effects of denosumab and alendronate. J Bone Miner Res. 2010;25(8):188694. https://doi.org/10.1002/jbmr.81.

28. Zebaze RM, Libanati C, Austin M, Ghasem-Zadeh A, Hanley DA, Zanchetta JR, et al. Differing effects of denosumab and alendronate on cortical and trabecular bone. Bone. 2014;59:173-9. https://doi.org/10.101 6/j.bone.2013.11.016.

29. Anastasilakis AD, Polyzos SA, Gkiomisi A, Saridakis ZG, Digkas D, Bisbinas I, et al. Denosumab versus zoledronic acid in patients previously treated with zoledronic acid. Osteoporos Int. 2015;26(10):2521-7. https://doi.org/10.1007/ s00198-015-3174-2.

30. Black DM, Delmas PD, Eastell R, Reid IR, Boonen S, Cauley JA, et al. Onceyearly zoledronic acid for treatment of postmenopausal osteoporosis. N Engl J Med. 2007;356(18):1809-22. https://doi.org/10.1056/NEJMoa067312.

31. Body JJ, Gaich GA, Scheele WH, Kulkarni PM, Miller PD, Peretz A, et al. A randomized double-blind trial to compare the efficacy of teriparatide [recombinant human parathyroid hormone (1-34)] with alendronate in postmenopausal women with osteoporosis. J Clin Endocrinol Metab. 2002; 87(10):4528-35. https://doi.org/10.1210/jc.2002-020334.

32. Black DM, Cummings SR, Karpf DB, et al. Randomised trial of effect of alendronate on risk of fracture in women with existing vertebral fractures. Fracture Intervention Trial Research Group. Lancet. 1996:348:1535-41.

33. Black DM, Schwartz AV, Ensrud KE, Cauley JA, Levis S, Quandt SA, et al. Effects of continuing or stopping alendronate after 5 years of treatment: the Fracture Intervention Trial Long-term Extension (FLEX): a randomized trial. JAMA. 2006;296(24):2927-38. https://doi.org/10.1001/jama.296.24.2927.

34. Black DM, Reid IR, Boonen S, Bucci-Rechtweg C, Cauley JA, Cosman F, et al. The effect of 3 versus 6 years of zoledronic acid treatment of osteoporosis: a randomized extension to the HORIZON-Pivotal Fracture Trial (PFT). J Bone Miner Res. 2012;27(2):243-54. https://doi.org/10.1002/jbmr.1494.

35. Black DM, Reid IR, Cauley JA, Cosman F, Leung PC, Lakatos P, et al. The effect of 6 versus 9 years of zoledronic acid treatment in osteoporosis: a randomized second extension to the HORIZON-Pivotal Fracture Trial (PFT). J Bone Miner Res. 2015;30(5):934-44. https://doi.org/10.1002/jbmr.2442.

36. Bone HG, Downs RW Jr, Tucci JR, et al. Dose-response relationships for alendronate treatment in osteoporotic elderly women. Alendronate Elderly Osteoporosis Study Centers. J Clin Endocrinol Metab. 1997;82(1):265-74. https://doi.org/10.1210/jcem.82.1.3682.
37. Brown JP, Roux C, Ho PR, Bolognese MA, Hall J, Bone HG, et al. Denosumab significantly increases bone mineral density and reduces bone turnover compared with monthly oral ibandronate and risedronate in postmenopausal women who remained at higher risk for fracture despite previous suboptimal treatment with an oral bisphosphonate. Osteoporos Int. 2014;25(7):1953-61. https://doi.org/10.1007/s00198-014-2692-7.

38. Brumsen C, Papapoulos SE, Lips P, Geelhoed-Duijvestijn PHLM, Hamdy NAT, Landman JO, et al. Daily oral pamidronate in women and men with osteoporosis: a 3-year randomized placebo-controlled clinical trial with a 2year open extension. J Bone Miner Res. 2002;17(6):1057-64. https://doi.org/1 0.1359/jbmr.2002.17.6.1057.

39. Chesnut CH 3rd, Skag A, Christiansen C, et al. Effects of oral ibandronate administered daily or intermittently on fracture risk in postmenopausal osteoporosis. J Bone Miner Res. 2004;19(8):1241-9. https://doi.org/10.1359/ JBMR.040325.

40. Clemmesen B, Ravn P, Zegels B, Taquet AN, Christiansen C, Reginster JY. A 2-year phase II study with 1-year of follow-up of risedronate (NE-58095) in postmenopausal osteoporosis. Osteoporos Int. 1997;7(5):488-95. https://doi. org/10.1007/PL00004152.

41. Cummings SR, Black DM, Thompson DE, Applegate WB, Barrett-Connor E, Musliner TA, et al. Effect of alendronate on risk of fracture in women with low bone density but without vertebral fractures: results from the Fracture Intervention Trial. JAMA. 1998;280(24):2077-82. https://doi.org/10.1001/ja ma.280.24.2077.

42. Cummings SR, San Martin J, McClung MR, et al. Denosumab for prevention of fractures in postmenopausal women with osteoporosis. N Engl J Med. 2009;361 (8):756-65. https://doi.org/10.1056/NEJMoa0809493.

43. Delmas PD, Ensrud KE, Adachi JD, Harper KD, Sarkar S, Gennari C, et al. Efficacy of raloxifene on vertebral fracture risk reduction in postmenopausal women with osteoporosis: four-year results from a randomized clinical trial. J Clin Endocrinol Metab. 2002;87(8):3609-17. https://doi.org/10.1210/jcem.87.8.8750.

44. Fogelman I, Ribot C, Smith R, et al. Risedronate reverses bone loss in postmenopausal women with low bone mass: results from a multinational, double-blind, placebo-controlled trial. BMD-MN Study Group. J Clin Endocrinol Metab. 2000;85:1895-900.

45. Frediani B, Allegri A, B S, et al. Effects of combined treatment with calcitriol plus alendronate on bone mass and bone turnover in postmenopausal osteoporosis two years of continuous treatment. Clin Drug Investig. 1998; 15(3):235-44. https://doi.org/10.2165/00044011-199815030-00008.

46. Jain MAA, Garg R. A comparative study of use of zoledronic acid and teriparatide in postmenopausal osteoporosis. J South Asian Feder Menopause Soc. 2015;3:6-8.

47. Gonnelli S, Caffarelli C, Tanzilli L, Pondrelli C, Lucani B, Franci BM, et al. Effects of intravenous zoledronate and ibandronate on carotid intima-media thickness, lipids and FGF-23 in postmenopausal osteoporotic women. Bone. 2014;61:27-32. https://doi.org/10.1016/j.bone.2013.12.017.

48. Greenspan SL, Perera S, Ferchak MA, Nace DA, Resnick NM. Efficacy and safety of single-dose zoledronic acid for osteoporosis in frail elderly women: a randomized clinical trial. JAMA Intern Med. 2015;175(6):913-21. https://doi. org/10.1001/jamainternmed.2015.0747.

49. Grey A, Bolland MJ, Wattie D, Horne A, Gamble G, Reid IR. The antiresorptive effects of a single dose of zoledronate persist for two years: a randomized, placebo-controlled trial in osteopenic postmenopausal women. J Clin Endocrinol Metab. 2009;94(2):538-44. https://doi.org/10.1210/jc.2008-2241.

50. Grey A, Bolland M, Wong S, Horne A, Gamble G, Reid IR. Low-dose zoledronate in osteopenic postmenopausal women: a randomized controlled trial. J Clin Endocrinol Metab. 2012;97(1):286-92. https://doi.org/1 0.1210/jc.2011-2081.

51. Guanabens N, Monegal A, Cerda D, et al. Randomized trial comparing monthly ibandronate and weekly alendronate for osteoporosis in patients with primary biliary cirrhosis. Hepatology. 2013;58(6):2070-8. https://doi. org/10.1002/hep.26466.

52. Harris ST, Watts NB, Jackson RD, Genant HK, Wasnich RD, Ross P, et al. Fouryear study of intermittent cyclic etidronate treatment of postmenopausal osteoporosis: three years of blinded therapy followed by one year of open therapy. Am J Med. 1993;95(6):557-67. https://doi.org/10.1016/0002-9343(93 )90350-X.

53. Harris ST, Watts NB, Genant HK, et al. Effects of risedronate treatment on vertebral and nonvertebral fractures in women with postmenopausal osteoporosis: a randomized controlled trial. Vertebral Efficacy With Risedronate Therapy (VERT) Study Group. JAMA. 1999;282:1344-52. 
54. Hooper MJ, Ebeling PR, Roberts AP, Graham JJ, Nicholson GC, D'Emden M, et al. Risedronate prevents bone loss in early postmenopausal women: a prospective randomized, placebo-controlled trial. Climacteric. 2005;8(3):25162. https://doi.org/10.1080/13697130500118126.

55. Iwamoto J, Sato Y, Uzawa M, Takeda T, Matsumoto H. Comparison of effects of alendronate and raloxifene on lumbar bone mineral density, bone turnover, and lipid metabolism in elderly women with osteoporosis. Yonsei Med J. 2008;49(1):119-28. https://doi.org/10.3349/ymj.2008.49.1.119.

56. Kendler DL, Bone HG, Massari F, Gielen E, Palacios S, Maddox J, et al. Bone mineral density gains with a second 12-month course of romosozumab therapy following placebo or denosumab. Osteoporos Int. 2019;30(12): 2437-48. https://doi.org/10.1007/s00198-019-05146-9.

57. Langdahl BL, Libanati C, Crittenden DB, Bolognese MA, Brown JP, Daizadeh NS, et al. Romosozumab (sclerostin monoclonal antibody) versus teriparatide in postmenopausal women with osteoporosis transitioning from oral bisphosphonate therapy: a randomised, open-label, phase 3 trial. Lancet. 2017; 390(10102):1585-94. https://doi.org/10.1016/S0140-6736(17)31613-6.

58. Leder BZ, Tsai JN, Uihlein AV, Wallace PM, Lee H, Neer RM, et al. Denosumab and teriparatide transitions in postmenopausal osteoporosis (the DATA-Switch study): extension of a randomised controlled trial. Lancet. 2015;386(9999):1147-55. https://doi.org/10.1016/S0140-6736(15)61120-5.

59. Leder BZ, Tsai JN, Uihlein AV, Burnett-Bowie SAM, Zhu Y, Foley K, et al. Two years of denosumab and teriparatide administration in postmenopausa women with osteoporosis (The DATA Extension Study): a randomized controlled trial. J Clin Endocrinol Metab. 2014;99(5):1694-700. https://doi. org/10.1210/jc.2013-4440.

60. Lewiecki EM, Dinavahi RV, Lazaretti-Castro M, Ebeling PR, Adachi JD, Miyauchi A, et al. One year of romosozumab followed by two years of denosumab maintains fracture risk reductions: results of the FRAME extension study. J Bone Miner Res. 2019;34(3):419-28. https://doi.org/10.1002/jbmr.3622.

61. Liang BC, Shi ZY, Wang B, Wu P, Kong LC, Yao JL, et al. Intravenous zoledronic acid $5 \mathrm{mg}$ on bone turnover markers and bone mineral density in East China subjects with newly diagnosed osteoporosis: a 24-month clinical study. Orthop Surg. 2017;9(1):103-9. https://doi.org/10.1111/os.12307.

62. Lufkin EG, Whitaker MD, Nickelsen T, Argueta R, Caplan RH, Knickerbocker RK, et al. Treatment of established postmenopausal osteoporosis with raloxifene: a randomized trial. J Bone Miner Res. 1998;13(11):1747-54. https://doi.org/10.1359/jbmr.1998.13.11.1747.

63. Lyritis GP, Tsakalakos N, Paspati I, Skarantavos G, Galanos A, Androulakis C. The effect of a modified etidronate cyclical regimen on postmenopausal osteoporosis: a four-year study. Clin Rheumatol. 1997;16(4):354-60. https:// doi.org/10.1007/BF02242451.

64. McClung MR, Grauer A, Boonen S, et al. Romosozumab in postmenopausal women with low bone mineral density. N Engl J Med. 2014;370(5):412-20. https://doi.org/10.1056/NEJMoa1305224.

65. McClung M, Miller P, Recknor C, Mesenbrink P, Bucci-Rechtweg C, Benhamou CL. Zoledronic acid for the prevention of bone loss in postmenopausal women with low bone mass: a randomized controlled trial. Obstet Gynecol. 2009;114(5):999-1007. https://doi.org/10.1097/AOG. Ob013e3181bdce0a.

66. McClung MR, Brown JP, Diez-Perez A, et al. Effects of 24 months of treatment with romosozumab followed by 12 months of denosumab or placebo in postmenopausal women with low bone mineral density: a randomized, double-blind, phase 2, parallel group study. J Bone Miner Res. 2018;33(8):1397-406. https://doi.org/10.1002/jbmr.3452.

67. Meunier PJ, Roux C, Seeman E, Ortolani S, Badurski JE, Spector TD, et al. The effects of strontium ranelate on the risk of vertebral fracture in women with postmenopausal osteoporosis. N Engl J Med. 2004;350(5):459-68. https://doi. org/10.1056/NEJMoa022436.

68. Meunier PJ, Roux C, Ortolani S, Diaz-Curiel M, Compston J, Marquis P, et al. Effects of long-term strontium ranelate treatment on vertebral fracture risk in postmenopausal women with osteoporosis. Osteoporos Int. 2009;20(10): 1663-73. https://doi.org/10.1007/s00198-008-0825-6.

69. Miller PD, Pannacciulli N, Brown JP, Czerwinski E, Nedergaard BS, Bolognese MA, et al. Denosumab or zoledronic acid in postmenopausal women with osteoporosis previously treated with oral bisphosphonates. J Clin Endocrinol Metab. 2016;101(8):3163-70. https://doi.org/10.1210/jc.2016-1801.

70. Montessori ML, Scheele WH, Netelenbos JC, et al. The use of etidronate and calcium versus calcium alone in the treatment of postmenopausal osteopenia: results of three years of treatment. Osteoporos Int. 1997;7(1):528. https://doi.org/10.1007/BF01623461.
71. Morii H, Ohashi Y, Taketani Y, Fukunaga M, Nakamura T, Itabashi A, et al. Effect of raloxifene on bone mineral density and biochemical markers of bone turnover in Japanese postmenopausal women with osteoporosis: results from a randomized placebo-controlled trial. Osteoporos Int. 2003; 14(10):793-800. https://doi.org/10.1007/s00198-003-1424-1.

72. Mortensen L, Charles P, Bekker PJ, Digennaro J, Johnston CC Jr. Risedronate increases bone mass in an early postmenopausal population: two years of treatment plus one year of follow-up. J Clin Endocrinol Metab. 1998:83(2): 396-402. https://doi.org/10.1210/jcem.83.2.4586.

73. Neer RM, Arnaud CD, Zanchetta JR, Prince R, Gaich GA, Reginster JY, et al. Effect of parathyroid hormone (1-34) on fractures and bone mineral density in postmenopausal women with osteoporosis. N Engl J Med. 2001;344(19): 1434-41. https://doi.org/10.1056/NEJM200105103441904.

74. Paggiosi MA, Peel N, McCloskey E, Walsh JS, Eastell R. Comparison of the effects of three oral bisphosphonate therapies on the peripheral skeleton in postmenopausal osteoporosis: the TRIO study. Osteoporos Int. 2014;25(12): 2729-41. https://doi.org/10.1007/s00198-014-2817-z.

75. Papapoulos S, Chapurlat R, Libanati C, Brandi ML, Brown JP, Czerwiński E, et al. Five years of denosumab exposure in women with postmenopausal osteoporosis: results from the first two years of the FREEDOM extension. J Bone Miner Res. 2012;27(3):694-701. https://doi.org/10.1002/jbmr.1479.

76. Papapoulos S, Lippuner K, Roux C, Lin CJF, Kendler DL, Lewiecki EM, et al. The effect of 8 or 5 years of denosumab treatment in postmenopausal women with osteoporosis: results from the FREEDOM Extension study. Osteoporos Int. 2015;26(12):2773-83. https://doi.org/10.1007/s00198-015-3234-7.

77. Popp AW, Buffat H, Cavelti A, Windolf M, Perrelet R, Senn C, et al. Cortical bone loss at the tibia in postmenopausal women with osteoporosis is associated with incident non-vertebral fractures: results of a randomized controlled ancillary study of HORIZON. Maturitas. 2014;77(3):287-93. https:// doi.org/10.1016/j.maturitas.2013.12.013.

78. Reginster JY, Bruyere O, Sawicki A, et al. Long-term treatment of postmenopausal osteoporosis with strontium ranelate: results at 8 years. Bone. 2009;45(6):1059-64. https://doi.org/10.1016/j.bone.2009.08.004.

79. Reginster JY, Kaufman JM, Goemaere S, Devogelaer JP, Benhamou CL, Felsenberg D, et al. Maintenance of antifracture efficacy over 10 years with strontium ranelate in postmenopausal osteoporosis. Osteoporos Int. 2012; 23(3):1115-22. https://doi.org/10.1007/s00198-011-1847-z.

80. Roux C, Hofbauer LC, Ho PR, Wark JD, Zillikens MC, Fahrleitner-Pammer A, et al. Denosumab compared with risedronate in postmenopausal women suboptimally adherent to alendronate therapy: efficacy and safety results from a randomized open-label study. Bone. 2014;58:48-54. https://doi.org/1 0.1016/j.bone.2013.10.006.

81. Tsai JN, Uihlein AV, Lee H, Kumbhani R, Siwila-Sackman E, McKay EA, et al. Teriparatide and denosumab, alone or combined, in women with postmenopausal osteoporosis: the DATA study randomised trial. Lancet. 2013;382(9886):50-6. https://doi.org/10.1016/S0140-6736(13)60856-9.

82. Tsai JN, Lee H, David NL, Eastell R, Leder BZ. Combination denosumab and high dose teriparatide for postmenopausal osteoporosis (DATA-HD): a randomised, controlled phase 4 trial. Lancet Diabetes Endocrinol. 2019;7(10): 767-75. https://doi.org/10.1016/S2213-8587(19)30255-4.

83. Tucci JR, Tonino RP, Emkey RD, Peverly CA, Kher U, Santora AC II. Effect of three years of oral alendronate treatment in postmenopausal women with osteoporosis. Am J Med. 1996;101(5):488-501. https://doi.org/10.1016/ S0002-9343(96)00282-3.

84. Jiang Y, Zhao JJ, Mitlak BH, Wang O, Genant HK, Eriksen EF. Recombinant human parathyroid hormone (1-34) [teriparatide] improves both cortical and cancellous bone structure. J Bone Miner Res. 2003;18(11):1932-41. https://doi.org/10.1359/jbmr.2003.18.11.1932.

\section{Publisher's Note}

Springer Nature remains neutral with regard to jurisdictional claims in published maps and institutional affiliations. 